УДК 32:316.646.32(477)

\title{
Ірина Кіянка,
}

доктор політичних наук, доцент кафедри європейської інтеграції та права, Львівський регіональний інститут державного управління

Національної академії державного управління

при Президентові України

kiyanka@i.ua

orcid/0000-0002-3100-7796

https://doi.org/10.29038/2524-2679-2020-01-223-229

\section{ІДЕЇ ПОПУЛІЗМУ У ВИБОРЧІЙ КАМПАНІЇ ПРЕЗИДЕНТА УКРАЇНИ 2019 РІК}

У статті здійснено аналіз ключових гасел, які активно використовувались у виборчій кампанії Президента України 2019 р. До уваги взято програми, у яких відображено реальні політичні вимоги та популістські гасла.

Вивчення популізму актуалізується наявністю соціального замовлення від зацікавлених суб'єктів політичної дії, які застосовують популізм для реалізаиії свойх програм та в боротьбі за владу.

У сучасних умовах політичне гасло лідера відіграє надзвичайно важливу роль у прочесі передвиборчої боротьби за владу. Гасло займає провідну нішу у виборчих технологіях $i$ забезпечує успіх політичного лідера у веденні виборчої кампанії. Як свідчить досвід останніх виборчих кампаній, політичне гасло досить часто асоиіюється з популізмом або стає популістським гаслом

Разом із цим актуальна сьогодні в Україні популістська категорія «народу», носія всіх чеснот, найвищої иүілі та мірила добра й зла, веде свій родовід ще від українського національно-демократичного руху XIX cm. із його виразно народницькими рисами. Новітній украӥнський національний рух певною мірою перейняв ї̈ як частину інтелектуальної спадщини від своїх історичних попередників, тим більше, щзо вона, як зазначалося вище, виявилася потрібною в роки вирішальної атаки на комуністичний режим.

Акцентовано, щзо популістські гасла у виборчі кампанії на пост Президента України 2019 р. сприймається, по-перше, як іноді спланована політична дія, за допомогою якої певна політична партія чи група політичних лідерів свідомо провокує та включає значну частину мас для втілення свойх маніпулятивних дій і реалізацію політичних технологій заради здобуття влади.

А по-друге, політична еліта вдало використовує національні образи, ідеї, символіку, щоб утвердити ие у свідомості більшої частини свого електорату й узяти під контроль політичну ситуацію в краӥні. Останнім часом спостерігаємо на полі украӥнського електорату, де з боку як опозиційних партій, так $i$ провладних усі готуються до виборів-2020 р., забуваючи свої передвиборчі обіиянки та програми.

Вибори в Україні втрачають значення механізму ствердження стандартів відповідальної державної політики. Це також є свідченням слабкості політичних партій, адже саме вони мають бути заџікавлені в зміцненні такого інституту демократії, як вибори, оскільки вибори дають змогу політичним партіям реалізувати себе. Виборча система й надалі залишається фактором соиіально-політичної напруженості, провокує політичні сили використовувати регіональні відмінності як інструмент політичної боротьби

(C) Кіянка I., 2020 
Ключові слова: популізм, вибори, гасло, політичний лідер, політичний режсим, демократія.

\section{1. ВСТУП}

Постановка проблеми. У сучасних умовах політичне гасло лідера відіграє надзвичайно важливу роль у процесі передвиборчої боротьби за владу. Гасло займає провідну нішу у виборчих технологіях і забезпечує успіх політичного лідера у веденні виборчої кампанії. Як свідчить досвід останніх виборчих кампаній, політичне гасло досить часто асоціюється 3 популізмом або стає популістським гаслом [1].

Гасло Помаранчевої революції 2004 р. було спровоковане бажанням українців вільно вибирати свою владу. I основну увагу зосереджено на масовості, натовпі людей, яких об єднувала пісня «Разом нас багато - нас не подолати», а бойовим кольором революції став помаранчевий колір.

Адже революція $є$ поворотним пунктом у розвитку історії, після якої все, що було після, не може бути таким, як було перед тим. Яка ж це була революція, якщо вона дала собі так швидко здатися? I чи не був Майдан узагалі одним великим і яскравим шоу, котре має мало спільного зі справжніми революційними подіями [2].

Гасло Революції гідності 2014 р. - це збереження людських чеснот і гідного життя, відкриття нових європейських цінностей [3]. Колапс цинізму й диктаторського режиму Януковича. Це новий етап розвитку українського суспільства 3 європейськими можливостями та активністю громадянського суспільства [4].

У теоретичних підходах часто не враховують усі можливі аспекти формування політичного іміджу лідера, такі як сутнісні характеристики постаті лідера, а також ситуації, що складаються в суспільстві [5].

Загалом, популізм як політична технологія та риторичний дискурс виявився в Україні властивий усім значним політичним гравцям. Водночас до останнього часу жодного 3 них не можна було схарактеризувати як переважно популістський, або «чисто популістський» [6].

Аналіз останніх досліджень і публікацій. Цією проблемою займалися численні науковці, які відобразили своє бачення в монографіях, наукових статтях, конференціях. А саме: К. Бондаренко, I. Варвар, Д. Видрін, О. Грищенко, А. Ковальчук, А. Колодій, В. Кривошеїн, Г. Почепцов, А. Романюк, В. Фесенко.

Мета статті полягає в аналізі проблематики популістських гасел у виборчій кампанії обрання Президента України 2019 р.

\section{2. РЕЗУЛЬТАТИ ДОСЛІДЖЕННЯ}

Виклад основного матеріалу. Отож проаналізуємо основні виборчі гасла провідних політичних лідерів у виборчій кампанії на пост Президента України 2019 p. 
Виборча кампанія В. Зеленського на пост Президента України обіцяла зробити заможним кожного українця через такі зміни, як запровадження «нульової декларації» для бізнесу - кожен бізнесмен за 5 \% зможе задекларувати та легалізувати свої доходи, а отримані кошти підуть на зменшення тарифів для малозабезпечених; заміна податку на прибуток податком на виведений капітал, що знизить адміністративний тиск на бізнес; детінізація економіки й свобода конкуренції; довгострокове доступне кредитування; формування прозорого ринку землі; перехід держави на власні енергоресурси; упровадження економічного паспорта українця - документа, який надасть змогу кожному 3 дня народження накопичувати на своєму рахунку частину від реалізації державою природних благ (надра, землі тощо), а після досягнення повноліття отримати ці накопичення як власний стартовий капітал [7].

Тодішній кандидат (а тепер уже чинний президент) обіцяв дати лікарям i вчителям гідні зарплати, а лікарням і школам - сучасне обладнання, а також запровадити страхову медицину, при цьому базовий рівень страхування для малозабезпечених - за рахунок держави, обов"еязковий безкоштовний щорічний медогляд; запровадження принципу «гроші ходять за талановитим студентом», тобто кожен школяр отримає освітній ваучер, який зможе витратити на навчання в будь-якому обраному ним ВНЗ; відкриття українського ринку для кращих іноземних закладів освіти.

Програма П. Порошенка на пост Президента України грунтувалася на таких чинниках, що в України існує єдиний шлях зберегти свою незалежність маємо стати великою європейською державою вільних і щасливих людей.

Наша місія - вступ до Євросоюзу й НАТО. Лише повноправне членство в Свропейському Союзі та Північноатлантичному альянсі остаточно та безповоротно гарантує нашу українську державну незалежність, нашу українську національну безпеку [8]. Історія XX й початку XXI ст. показала, що незалежна Українська держава - наріжний камінь демократії, свободи й миру в Європі, а також важлива складова частина безпеки та захисту всієї євроатлантичної спільноти. Ми - країна, яка вже суттєво посилила східний фланг Альянсу й захистила від російської агресії не лише себе, а й усю європейську цивілізацію. У 2023-му ми подамо заявку на вступ до ЄС, отримаємо та почнемо виконувати План дій щодо членства в НАТО. Завдяки членству в ЄC i HАTO забезпечимо високі стандарти життя людей; верховенство права й рівні правила для всіх; допомогу в розвитку економіки всієї держави та регіонів; доступ до найбільшого світового ринку; безпеку й захист держави, бо основний принцип НАТО - це «один за всіх, всі за одного».

Аналізуючи виборчу програму Ю. Тимошенко, звернемо увагу, що після того, як українці, ризикуючи своїми життями, довели, що вони гідні жити в європейській, демократичній країні, політики більше не мають права ізолювати ïх від впливу на ухвалення державних рішень. Воля громадян повинна бути вищою від волі політиків і враховуватися постійно, а не лише раз на п“ять років, коли люди віддають свій голос за кандидатів на виборах. Тому потрібно: 
1. Запровадити механізм приватного обвинувачення, коли громадяни можуть напряму звертатися до суду для притягнення до відповідальності чиновників, які порушують права людини та закони.

2. Провести люстрацію й притягти до відповідальності суддів, прокурорів, працівників міліції, усіх посадовців, причетних до політичних переслідувань, порушень прав людини, неправосудних рішень, невиконання рішень Свропейського суду з прав людини та до корупції.

3. Скасувати недоторканість народних депутатів, суддів i Президента України. Запровадити дієвий механізм імпічменту Президента.

4. Запровадити механізм відкликання народного депутата та щорічне декларування чиновниками своїх доходів і видатків [9].

Запровадити податок на розкіш не лише для фізичних, але й для юридичних осіб, на яких чиновники-корупціонери записують своє майно, уникаючи оподаткування.

Здійснити ревізію та міжнародний аудит результатів державних закупівель i приватизації, здійснених попередньою владою. Арештувати й повернути Україні незаконно відчужену власність та кошти держбюджету, які корупційним шляхом були виведені за кордон. Перекрити канали виведення олігархами з України в офшори мільярдів доларів.

Змусити олігархів сплачувати податки в повному обсязі в Україні. Відкрити по всій країні мережу «універсамів адмінпослуг», щоб громадянин в одному місці в зручний для себе час без черг та хабарів міг отримати пакет адміністративних послуг від держави.

Лідер «Радикальної партії» О. Ляшко обіцяв зменшити ціни на газ, скоротити кількість народних депутатів до 250, а також залишити лише 10 міністерств. Також Ляшко хоче виплачувати дотації на кожну корову, запровадити державне регулювання цін на ліки й продукти, ухвалити закон «Купуй українське», який, як попереджають експерти, фактично вбиває систему ProZorro. Його програма - це економічний популізм, заклик витрачати більше та заробляти менше, а це - шлях до економічної кризи.

Не міжнародні рейтинги, а доходи і якість життя українців! Не закордонні кредити на проїдання, а інвестиції в розвиток економіки! Не імпорт іноземної продукції, а підтримка національного виробника! Не вимоги Міжнародного валютного фонду (МВФ), а інтереси українського народу! Не огульна приватизація, а ефективне управління державним майном! Не продаж сільськогосподарських земель, а захист селян! Не підвищення комунальних тарифів, а енергомодернізація та власний видобуток газу! Не «витискання соків» із підприємців, а інвестиційні стимули й обмеження перевірок! Не економія на науці та освіті, а ставка на інтелект й інновації! Не масова еміграція, а створення робочих місць в Україні як пріоритет №1! [10].

А. Гриценко виступав, насамперед, за чесну судову систему, яка, на думку кандидата, має допомогти залучити іноземні інвестиції. Також Гриценко вважає, що треба зробити життєздатною антикорупційну реформу й повернути Крим та окуповану частину Донбасу. А. Гриценку, як і іншим 
кандидатам, властивий популізм. Він гарантує робоче місце кожному, хто отримає освіту за державним замовленням. Цей кандидат може обеєднати навколо себе частину ліберального електорату [11].

В останні кілька років популізм в Україні використовується для просування партій-«проектів», що створені насамперед для обстоювання певних бізнес-інтересів. Вищеназвані чинники роблять його доволі успішною технологією, принаймні в короткотривалій перспективі [13].

3 іншого боку, спостерігаємо загострення електоральної конкуренції між популістськими політичними гравцями. Вражаючий успіх деяких популістів, які не здатні виконати свої нереальні обіцянки, легко може обернутися таким самим вражаючим крахом. Утім, український популізм є надто гнучким, багатовимірним феноменом і, треба думати, у найближчі роки залишиться, хоча й у відмінних формах і з іншими вождями, впливовим чинником політичної боротьби в Україні [14].

Вибори 2019 р. й надалі повторюють ті ж самі помилки, які допускали й політики попередніх років. Наповнення політичних програм великою кількістю обіцянок і галасливих слів, а практична реалізація залишається мізерною та, на жаль, популістською.

На нашу думку, існує декілька чинників чималого й тривалого впливу популізму в незалежній Україні. Одним із них, що вже називався вище, вважаємо якість політичної культури, насамперед таку їі складову частину, як несформованість у багатьох громадян здатності до критичного осмислення складних соціально-економічних та політичних реалій, схильність робити негайні й надто прості висновки стосовно непростих і суперечливих речей. Підвалини такого стану справ закладено протягом кількох десятиліть радянського періоду української історії, коли за відсутності основних свобод, реальної публічної політики та дискусій, достатньої культури аргументацій, доказового аналізу, вочевидь, не могла сформуватися.

Разом із цим актуальна сьогодні в Україні популістська категорія «народу», носія всіх чеснот, найвищої цілі й мірила добра та зла, веде свій родовід ще від українського національно-демократичного руху XIX ст. 3 його виразно народницькими рисами. Новітній український національний рух певною мірою перейняв іiі, як частину інтелектуальної спадщини, від своїх історичних попередників, тим більше, що вона, як зазначалося вище, виявилася потрібною в роки вирішальної атаки на комуністичний режим.

\section{3. ВИСНОВКИ ТА ПЕРСПЕКТИВИ ПОДАЛЬШИХ ДОСЛІДЖЕНЬ}

Можна зробити висновки, що популістські гасла у виборчі кампанії на пост Президента України 2019 р. сприймається, по-перше, як іноді спланована політична дія, за допомогою якої певна політична партія чи група політичних лідерів свідомо провокує та включає значну частину мас для втілення своїх маніпулятивних дій і реалізацію політичних технологій заради здобуття влади. 
А по-друге, політична еліта вдало використовує національні образи, ідеї, символіку, щоб утвердити це у свідомості більшості свого електорату й узяти під контроль політичну ситуацію в країні. Останнім часом спостерігаємо на полі українського електорату, де з боку як опозиційних партій, так і провладних усі готуються до виборів-2020 р., забуваючи свої передвиборчі обіцянки та програми.

Вибори в Україні втрачають значення механізму ствердження стандартів відповідальної державної політики. Це також $є$ свідченням слабкості політичних партій, адже саме вони мають бути зацікавлені в зміцненні такого інституту демократії, як вибори, оскільки саме вони дають змогу політичним партіям реалізувати себе. Виборча система й надалі залишається фактором соціально-політичної напруженості, провокує політичні сили використовувати регіональні відмінності як інструмент політичної боротьби.

\section{СПИСОК ВИКОРИСТАНИХ ДЖЕРЕЛ}

1. Грицак, Я. Що залишилося після Помаранчевої револючії? Київ: Вид. дім «КиєвоМогилянська академія», 2010. $31 \mathrm{c.}$

2. Сшкілєв, В. Політична вулиця України: пошуки упирів та героїв. URL: http://zaxid.net/home/showSingleNews.dopolitichna_vulitsya_ukrayini_poshuki_upiriv_ta_geroyiv \&objectId $=127220$

3. Ковальчук, В. Кандидатський мінімум. URL: http://klichko.org/ua/news/publications/ kandidatskiy-praktikum.

4. Ситник, О. М. (2009). Становлення ідеології: украӥнський аспект: монографія. Донецьк: Вид-во «Вебер» (Донецька філія), 244 с.

5. Наход, М. (2012). Виборчі системи та їх вплив на управління виборчим процесом (історико-порівняльний аспект). (Автореф. дис. ... канд. наук з державного управління). Львів, 20 с.

6. Панасюк, Б. Я. (2006). Помаранчева революичя в променях національної ідеї: історико-художній нарис. Київ: КНЕУ, 176 с.

7. Передвиборна програма кандидата на пост президента Володимира Зеленського 2019. URL: https:// program.ze2019.com

8. Передвиборна програма Петра Порошенка 2019. URL: https://lb.ua/news/2019/ 02/11/419445_peredviborcha_programa_petra.html

9. Передвиборна програма Юлї Тимошенко 2019. URL: https://lb.ua/news/2019/ 02/11/419453_peredviborna_programa_yuli.html

10. Передвиборна кампанія Олега Ляшка 2019. URL: https:// http://liashko.ua/program

11. Передвиборна програма Анатолія Грищенко 2019. URL: https //www.grytsenko.com. ua/programa-kandidata/

12. Політична система і громадянське суспільство: європейські і українські реалії: монографія (За заг. ред. д-ра іст. наук, проф. А. І. Кудряченка). Київ: НІСД, 2007. 396 с.

\section{POPULISM IDEAS IN THE 2019 ELECTION CAMPAIGN OF THE PRESIDENT OF UKRAINE}

The article analyzes key slogans that were actively used in the 2019 presidential election campaign. Programs that reflected real political demands and populist slogans were taken into account.

The study of populism is updated by the existence of a social order from interested political actors who use populism to implement their programs and fight for power. 
In our opinion, there are several factors behind the considerable and lasting impact of populism in independent Ukraine. One of the aforementioned, we consider the quality of political culture, above all its component, as the lack of ability of many citizens to critically comprehend complex socio-economic and political realities, the tendency to make immediate and too simple conclusions about difficult and contradictory things.

At the same time, the populist category of «people» - the bearer of all virtues, the highest purpose and the measure of good and evil - is relevant today in Ukraine, leading from the Ukrainian national-democratic movement of the 19th century, with its distinctly populist features. The new Ukrainian national movement has, to a certain extent, taken it as part of its intellectual heritage from its historical predecessors, especially since, as noted above, it was necessary during the decisive attack on the communist regime.

In the last few years, populism in Ukraine of letters that are incapable of delivering on their unrealistic promises can easily turn into a similarly striking collapse. However, Ukrainian populism is a very flexible, multidimensional phenomenon, and it should be thought that in the coming years it will remain, though in different forms and with other leaders, an influential factor in Ukraine's political struggle.

The elections in Ukraine are losing the value of a mechanism for establishing standards of responsible public policy. This is also a testament to the weakness of political parties, because it is they who should be interested in strengthening such an institution of democracy as elections, since it is elections that allow political parties to exercise themselves. The electoral system continues to be a factor in socio-political tensions, provoking political forces to use regional differences as an instrument of political struggle.

Key words: populism, elections, political leader, political regime, democracy.

\section{REFERENCES}

1. Hrytsak, Ya. (2010). Shcho zalyshylosia pislia Pomaranchevoi revoliutsii? Kyiv: Vyd. dim «Kyievo-Mohylianska akademiia», $31 \mathrm{p}$.

2. Yeshkiliev, V. Politychna vulytsia Ukrainy: poshuky upyriv ta heroiv. URL: http://zaxid.net/home/showSingleNews.dopolitichna_vulitsya_ukrayini_poshuki_upiriv_ta_geroyiv \&objectId $=127220$

3. Kovalchuk, V. Kandydatskyi minimum. URL: http://klichko.org/ua/news/publications/ kandidatskiy-praktikum.

4. Sytnyk, O. M. (2009). Stanovlennia ideolohii: ukrainskyi aspekt: monohrafiia. Donetsk: Vyd-vo «Veber» (Donetska filiia), $244 \mathrm{p}$.

5. Nakhod, M. (2012). Vyborchi systemy ta yikh vplyv na upravlinnia vyborchym protsesom (istoryko-porivnialnyi aspekt). (Avtoreferat dys. ... kand. nauk z derzhavnoho upravlinnia). Lviv, 20 p.

6. Panasiuk, B. Ya. (2006). Pomarancheva revoliutsiia v promeniakh natsionalnoi idei: istoryko-khudozhnii narys. Kyiv: KNEU, 176 p.

7. Peredvyborna prohrama kandydata na post prezydenta Volodymyra Zelenskoho 2019. URL: https:// program.ze2019.com

8. Peredvyborna prohrama Petra Poroshenka 2019. URL: https://lb.ua/news/2019/02/11/ 419445_peredviborcha_programa_petra.html

9. Peredvyborna prohrama Yulii Tymoshenko 2019. URL: https://lb.ua/news/2019/02/11/ 419453_peredviborna_programa_yuli.html

10. Peredvyborna kampaniia Oleha Liashka 2019. URL: https:// http://liashko.ua/program

11. Peredvyborna prohrama Anatoliia Hryshchenko 2019. URL: https //www.grytsenko.com. ua/programa-kandidata/

12. Politychna systema i hromadianske suspilstvo: yevropeiski i ukrainski realii: monohrafiia (Za zah. red. d-ra ist. nauk, prof. A. I. Kudriachenka). Kyiv: NISD, 2007. 396 p. 